\title{
Synonymy between Lymnaea bogotensis Pilsbry, 1935 and Lymnaea cousini Jousseaume, 1887 (Gastropoda: Lymnaeidae)

\author{
Luz Elena Velásquez
}

\author{
Programa de Estudio y Control de Enfermedades Tropicales, Escuela de Bacteriología y Laboratorio Clínico, Universidad de \\ Antioquia, Sede de Investigación Universitaria, Calle 62 \# 52-59, 7 piso, 730, Medellín, Colombia
}

The lymneid snail Lymnaea bogotensis Pilsbry 1935 is synonymized with L. cousini Jousseaume 1887, based on morphological comparisons of the reproductive systems. The shell, renal tube, and reproductive system are described and illustrated from specimens collected in the type locality and the municipality of Paipa, Colombia. Bibliographical records reveal $\mathrm{L}$. columella to be the commonest lymneid in the country. The latter two species can be differentiated based on the morphology of the penial complex.

Key words: Lymnaea bogotensis - Lymnaea cousini - synonymy - taxonomy - Colombia

Members of the family Lymnaeidae are pulmonate molluscs present in continental aquatic ecosystems throughout the world. About 100 species have been described, most in the Holarctic region with a few representatives in the Neotropics (Hubendick 1951).

A few species of lymneids are important in medical malacology because of their roles in the transmission of digeneid parasites such as Fasciola spp. and Paramphistomum spp., responsible for fasciolosis in bovines and humans as well as paramphistomosis in ruminants (Malek 1985). Since these diseases generate huge economic losses in livestock production in tropical and subtropical countries of all continents, intervention methods are needed to control their expansion and reduce their respective prevalences (WHO 1995). Populations of lymneid species that act as hosts for these parasites also become the object of epidemiological vigilance. Furthermore, studies to identify potential vectors and map their distributions are important in determining zones at risk from disease.

Paraense (1976a, 1982a, b, 1983, 1984, 1995, 2004) made the most important taxonomic studies of South American Lymnaea, describing the morphological characters of the reproductive system, kidney, and shell of each species in detail. This methodology was applied by Oviedo et al. (1995) and Samadi et al. (2000) in their studies on lymneids of the Bolivian plateau, the results of which were confirmed by isoenzyme and molecular techniques (Carvalho et al. 2004). Pointier et al. (2004) also used this methodology in studies of Venezuelan species.

Three species of Lymnaea have been reported in Colombia, including L. ubaquensis Piaget, 1914, and L. bogotensis Pilsbry, 1935; new species whose respective type localities are Laguna de Ubaque and Bogotá, both in the department of Cundinamarca above 2500 masl. The latter species was incriminated by Brumpt et al. (1940)

Financial support: Colciencias, grant 1115-05-13664

E-mail: luzelena333@yahoo.com

Received 19 June 2006

Accepted 16 August 2006 and Muñoz-Rivas (1953) as host of Fasciola hepatica in this region. It has been suggested that both species are synonyms of L. cousini (Hubendick 1951, Pointier et al. 2004). On the other hand the lymneid that presents the widest geographical distribution in Colombia is $L$. columella (Say 1817), which inhabits aquatic ecosystems from sea level to 2600 masl and has been identified as an intermediate host of $F$. hepatica (Patiño 1978, Malek \& Congswell 1980, Malek 1985, Gómez 1990).

Despite their epidemiological importance, there is considerable confusion in the systematics of Colombian lymneids. The formal descriptions of L. ubaquensis and L. bogotensis include photographs and some characteristics of the shells but lack detailed descriptions and drawings of their internal structures, needed to help establish the status of each as a species.

This paper confirms that L. bogotensis Pilsbry 1935 is synonymous with L. cousini Jousseaume 1887, based on morphological comparisons.

L. bogotensis Pilsbry (1935: 88. Plate 6, Fig. 9) was briefly described as follows: Maria.

“Bogotá. Type 164556 A.N.S.P., collected by Hmo. Apolinar

The shell is umbilicate, ovate, thin, light brown, with short, conic spire; glossy, with fine, irregular striae and wrinkles of growth, which, above the periphery, are cut into long granules by some indistinct spirals. The large aperture is oblique, ovate, broadly rounded below. Columella dilated above, passing in a very wide angle into the thickened parietal callus. There is a distinct, long fold, chiefly visible in an oblique view in the mouth. Length $13.7 \mathrm{~mm}$., diam. $8.6 \mathrm{~mm}$., length aperture $9.8 \mathrm{~mm}$ ".

\section{MATERIALS AND METHODS}

Type locality - Five specimens of L. bogotensis in formaldehyde (shells and soft tissues) were obtained from the collection of the Instituto Nacional de Ciencias of the Universidad Nacional de Colombia. These snails were collected in 1974 in the south of Bogotá $\left(4^{\circ} 35^{\prime} 56^{\prime \prime} \mathrm{N} ; 74^{\circ}\right.$ 04' 51"W).

Other locality - Snails were collected from a stream, the Quebrada Toibita (5'47'04" N; 730 06' 47" W) at Paipa (Boyacá) in May and December 2003. They were trans- 
ported live to the laboratory and maintained on fresh lettuce in aquaria provided with artificial aeration, dechlorinated water and sterile mud substrate. Thirty adult specimens were selected for taxonomic studies. The snails were relaxed in $0.05 \%$ Nembutal for $8 \mathrm{~h}$ and sacrificed by immersion in water at $70^{\circ} \mathrm{C}$. The soft tissues were separated, fixed in Railliet-Henry solution and dissected following the methodology proposed by Deslandes (1951) and Paraense $(1966,1975,1976 b, 1988)$. Measurements of the reproductive system were carried out with a micrometer linked to an optical microscope $( \pm 0.01 \mu \mathrm{m})$. Shell measurements were taken with a digital calibrator $( \pm 0.01 \mu \mathrm{m})$ and stored in recipients sealed with cotton wool. The kidney and reproductive system of each specimen were illustrated using a camera lucida.

Specimens from the type locality and Paipa were deposited in the collection of the Programa de Estudio y Control de Enfermedades Tropicales within the Instituto Alexander von Humboldt, VHET 37, Colombia (PECET MOL 85-86, 317-319).

\section{DESCRIPTION}

The largest shell (Fig. 1) was $11.7 \mathrm{~mm}$ high and $7 \mathrm{~mm}$ wide; height of spire $4.6 \mathrm{~mm}$, aperture $7.1 \mathrm{~mm}$ high and $5.3 \mathrm{~mm}$ wide. The following ratios were calculated for the 35 specimens, with spire heights of 3.1-11.7 mm (6.85 \pm 2.3): shell width/shell height $=0.54-0.71(0.62 \pm 0.05)$; spire height $/$ shell height $=0.24-0.45(0.36 \pm 0.05)$; aperture height/shell height $=0.55-0.76(0.64 \pm 0.05)$; aperture height/spire height $=1.23-3.17(1.84 \pm 0.41)$. From these ratios it was inferred that the aperture constitutes about $2 / 3$ of the total shell height. Qualitative characters of the shells are as follows: light brown, umbilicate, thin, with short spire and fine growth lines. Aperture large, oblique, oval and wide at the base, with a fold in the middle part of the parietal wall, on which a thin white callus can also be observed.

The renal tube (Fig. 2A) extends diagonally across the roof of the palial cavity, from the pericardial region to the

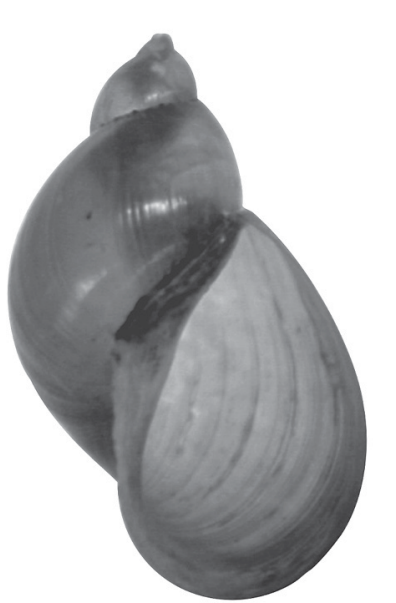

A

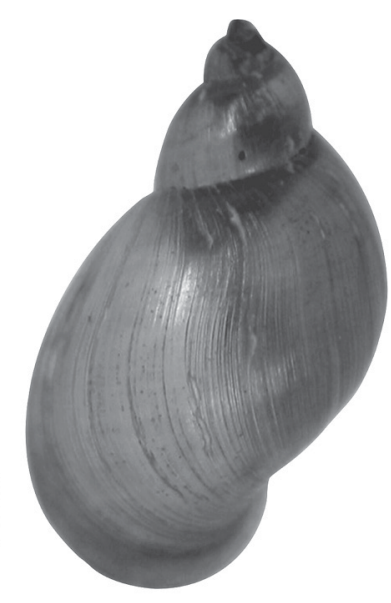

B
Fig. 1: shell of Lymnaea cousini from Bogotá Savannah, Colombia. A: ventral view; B: dorsal view. Scale bar $=1 \mathrm{~mm}$. Photography by LE Velásquez. mantle collar, where it folds over to the left and returns as a ureter that opens out into a meatus to the right of the osphradium. The ovotestis (Fig. 2C) is a mass of compact sigmoid tubes that opens into a ovispermiduct, in which can be observed very short lateral, digitiform structures that comprise the seminal vesicle along the first two-thirds of its length. The last third of the ovispermiduct is very thin and simple and terminates in the carrefour. The milky white albumen gland lies on the carrefour and the first portion of the oviduct, hiding the origin of these structures.

The oviduct is a transverse tubular structure, curled over at the extremities. Its region proximal to the albumen gland is smaller than the distal region, which is formed by larger, dilated tubes and continues as the nidamental gland. The nidamental gland is compact with transverse striations. At the base of this structure lies the uterus which has a softer aspect and vertical striations. A prolongation to one side forms the short, bulbous vagina, opening to the exterior through the female genital pore.

The spermatheca is a spherical yellow structure with a canal which separates from the centre of the vagina and crosses diagonally between the prostate and the nidamental gland. It reaches the roof of the palial cavity close to the pericardium. The spermiduct leaves the carrefour beside ov 1 and continues along a depression in the middle of the ventral region of the nidamental gland. Its small cells give it a granular aspect. It opens into the prostate (Fig. 2B), which is wide and concave with folds, its cells being larger than those of the spermiduct.

A funnel emerges from the dorsum of the distal region of the prostate, the vas deferens. This narrows until it attains its smallest diameter in the first third of its length; it then continues somewhat thicker and more sinuous to the penis which lies within the penial sheath (Fig. 3) whose proximal extremity is somewhat thicker and bears a ring of papillae. The penial sheath is cylindrical, with a length 1.5 $\times$ that of the prepuce (range 1.30-1.96, mean $1.5 \pm 0.24$ ). This is thicker at the point of insertion of the penial sheath and terminates in the male genital pore, whose borders are lightly thickened.

\section{DISCUSSION}

The qualitative characters of the shell described in this study coincide with those given by Pilsbry (1935) for L. bogotensis. Furthermore, the shell measurement ratios and internal structures such as the kidney and the reproductive system resemble those in the re-description of $L$. cousini Jousseaume, 1887 by Paraense (1995), in the specimens collected in Bogotá in 1974 as well as those from Paipa in 2003. Colombian specimens of $L$. cousini thus occur within the altitudinal range reported for this species in other Neotropical countries (Pointier et al. 2004, Paraense 2004)

In summary, the specimens described unite a complex of characteristics that coincide exactly with those given for L. cousini by Paraense (1995). Thus L. bogotensis Pilsbry, 1935 is a synonym of $L$. cousini Jousseaume, 1887.

Some of the specimens of $L$ cousini collected in Paipa were parasitized with $F$. hepatica, which constitutes proof of its role as a host of the digeneid and supports the 
conclusions of other authors (Pointier et al. 2004, Villavicencio \& Carvalho de Vasconcellos 2005). Although Physa acuta was collected in nine aquatic ecosystems in the Sabana de Bogotá by Velásquez and Escobar (2001), lymneids identified as L. columella were obtained from only one of these. The shell of this species is similar to that of $L$. cousini, given that in both the aperture is about $2 / 3$ of the total height; but they differ in the characteristic microsculptures of the periostracum present in L. columella, which are absent in L. cousini (Pointier et al. 2005).
The two species also resemble each other in the double flexing of the ureter, but can be differentiated by comparing the morphology of the penial complex. In L. cousini it is very conspicuous and consists of a wide prepuce with a penial sheath that is always $1.5 \times$ longer, while in $L$. columella the prepuce is very slender and the penial sheath much shorter $(0.26 \times)$. The prostate of $L$. cousini is large and voluminous while that of $L$. columella is very thin.

This study illustrates the importance of comparative

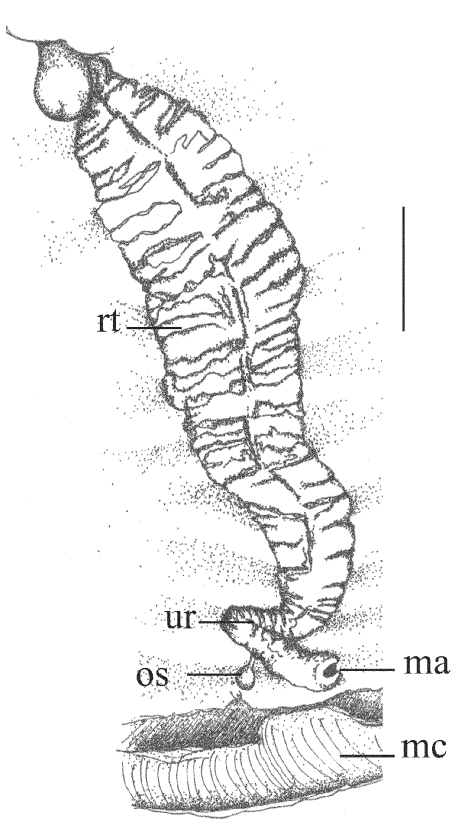

A

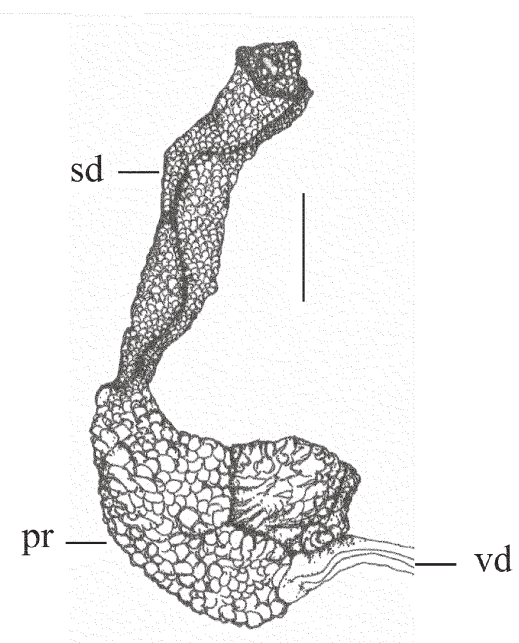

B

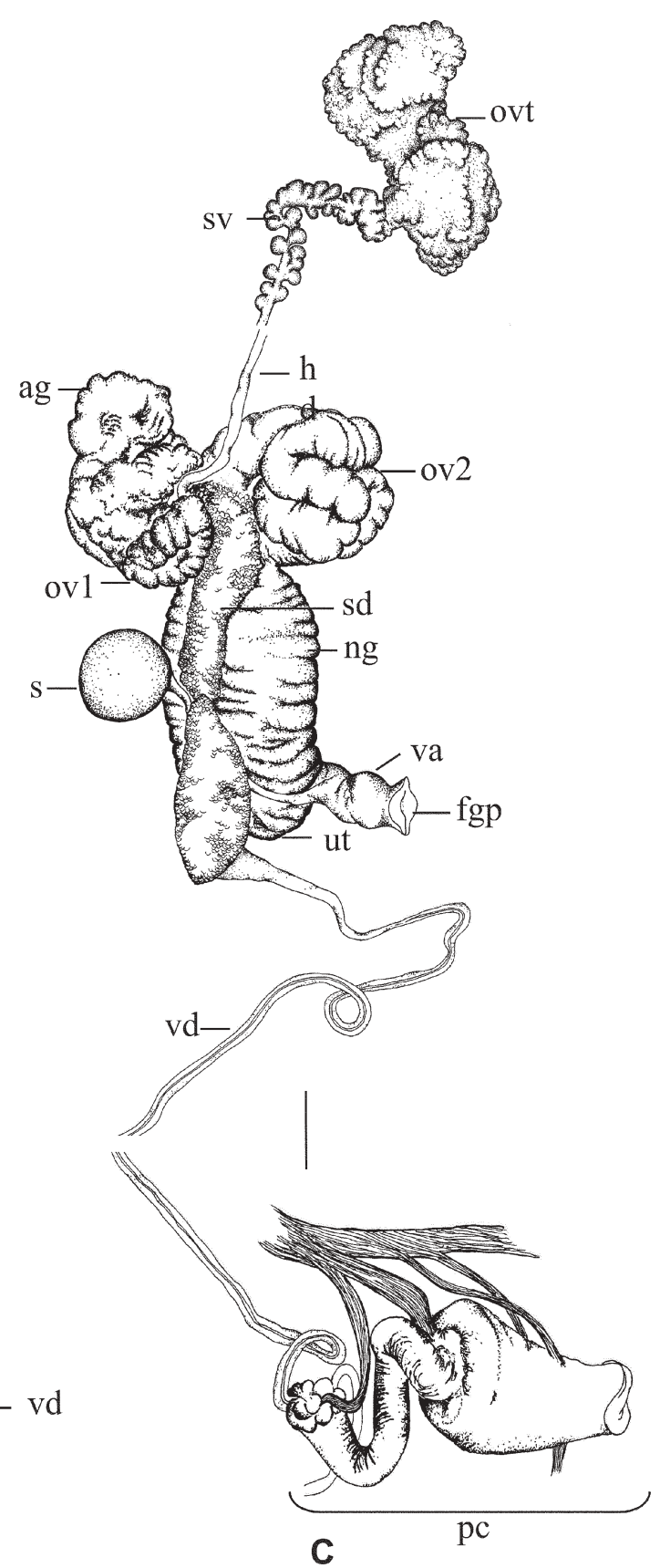

C

Fig. 2: Lymnaea cousini from Bogotá Savannah. A: kidney; scale bar $=1 \mathrm{~mm}$; B: spermiduct and prostate; scale bar $=1 \mathrm{~mm}$; C: reproductive system, scale bar $=0.5 \mathrm{~mm}$. Abbreviations: ag, albumen gland; fgp, female genital pore; $\mathrm{h}$, hermaphroditic duct; mc, mantle collar; ma, meatus; ng, nidamental gland; os, osphradium; ov1, proximal portion of oviduct; ov2, distal portion of oviduct; ovt, ovotestis; pc, peneal complex; pr, prostate; rt, renal tube; s, spermateca; sd, spermiduct; sv, seminal vesicle; ut, uterus; ur, ureter; va, vagina; vd, vas deferens. 


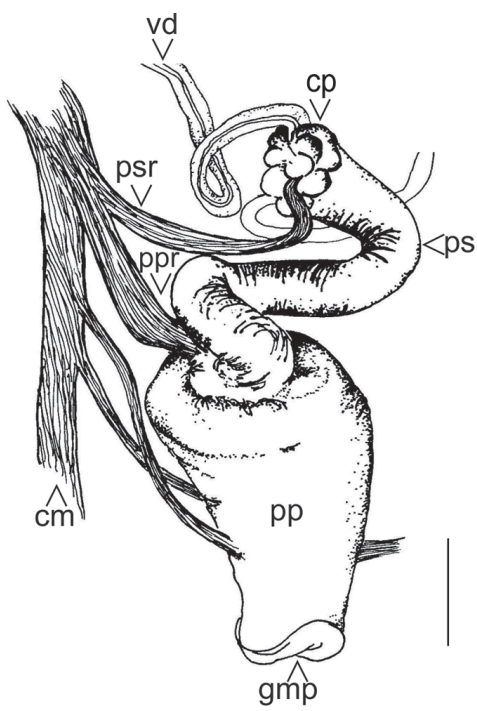

A

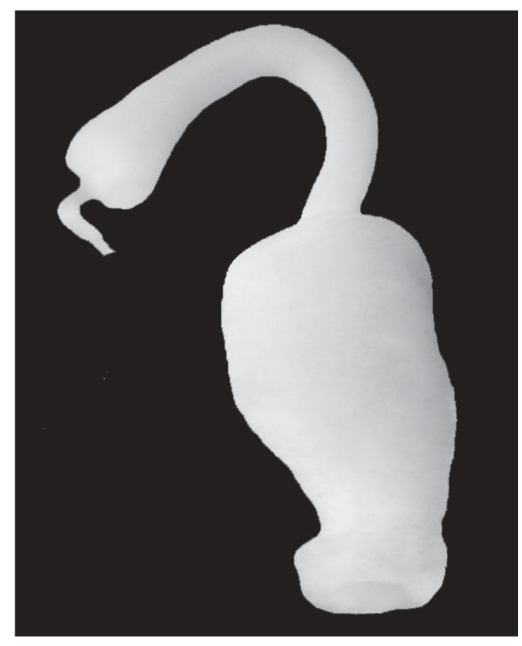

B

Fig. 3: Lymnaea cousini from Bogotá Savannah. A: penial complex; abbreviations: cm, columellar muscle; cp, circle of papillae; gmp, genital male pore; pp, prepuce; ppr, prepuce retractor; ps, penial sheath; psr, penial sheath retractor; vd, vas deferens; B. Penial complex. Photography by LE Velásquez; scale bar $=0.5 \mathrm{~mm}$.

descriptions of the reproductive system, particularly the penial complex, in the taxonomy of Colombian lymnaeids.

\section{ACKNOWLEDGEMENTS}

To Dr Wladimir Lobato Paraense for suggesting this research topic and for his guidance and support. To Dr Iván Darío Vélez for his continued support of our research on Colombian snail vectors. To biologist Erika P Alarcón for collecting and transporting the specimens from Paipa. To María Carmenza Hincapie for the drawings.

\section{REFERENCES}

Brumpt E, Velásquez J, Ucross H, Brumpt LCh 1940. Découverte de l'hôte intermédiare Limnaea bogotensis Pilsbry, de la grande douve Fasciola hepatica, en Colombie. Ann Parasit Paris 17: 563.

Carvalho OS, Cardoso P, Lira PM, Rumi A, Roche A, Berne E, Müller G, Caldeira RL 2004. The use of the polymerase chain reaction and restriction fragment length polymorphism technique associated with the classical morphology for characterization of Lymnaea columella, L. viatrix, and $L$. diaphana (Mollusca: Lymnaeidae), Mem Inst Oswaldo Cruz 99: 503-507.

Deslandes N 1951. Técnica de dissecação e exame de planorbídeos. Rev Serv Esp Saúde Púb 4: 371-382.

Gómez T 1990. Ciclo de vida de Fasciola hepatica (Linnaeus, 1758) e identificación de su huésped intermediario en algunas zonas ganaderas del departamento del Tolima. Rev Univ Tol Cienc Tecnol 5: 45-75.

Hubendick B 1951. Recent Lymnaeidae; their variation, morphology, taxonomy, nomenclature, and distribution. Kungl Svenska Vetenskapsakad Handl (4 ser) 3: 1-223.

Jousseaume F 1887. Mollusques nouveaux de la Republique de l'Equateur. Bull Soc Zool France 12: 165-186.

Malek E 1985. Snail Hosts of Schistosomiasis and other Snail- transmitted Diseases in Tropical America: A Manual, PAHO Scientific Publication no. 478, 325 pp.

Malek E, Congswell FB 1980. Lymnaea (Pseudosuccinea) columella in Colombia. Nautilus 94: 112-114.

Muñoz-Rivas G 1953. Fasciolosis experimental. Rev Acad Colomb Cienc 9: 156-158.

Oviedo JA, Bargues MB, Mas-Coma S 1995. Lymnaeid snails in the human fasciolasis high endemic zone of the northern Bolivian altiplano. Res Rev Parasitol 55: 35-43.

Paraense WL 1966. Biomphalaria amazonica and B. cousini, two new species of Neotropical planorbid mollusks. Rev Brasil Biol 26: 115-126.

Paraense WL 1975. Estado atual da sistemática dos planorbídeos brasileiros. Arq Mus Nac 55: 105-128.

Paraense WL 1976a. Lymnaea viatrix: a study of topotypic specimens (Mollusca: Lymnaeidae). Rev Brasil Biol 36: 419428.

Paraense WL 1976b. A natural population of Helisoma duryi in Brazil. Malacology 15: 360-376.

Paraense WL 1982a. Lymnaea viatrix and Lymnaea columella in the Neotropical Region: a distributional outline. Mem Inst Oswaldo Cruz 77: 181-188.

Paraense WL 1982b. Lymnaea rupestris sp. n. from Southern Brazil (Pulmonata: Lymnaeidae). Mem Inst Oswaldo Cruz 77: 437-443.

Paraense WL 1983. Lymnaea columella in Northern Brasil. Mem Inst Oswaldo Cruz 79: 75-81.

Paraense WL 1984. Lymnaea diaphana: a study of topotypic specimens (Pulmonata: Lymnaeidae). Mem Inst Oswaldo Cruz 79: 75-81.

Paraense WL 1988. Biomphalaria kuhniana (Clessin, 1883), planorbid mollusc from South America. Mem Inst Oswaldo Cruz 83: 1-12. 
Paraense WL 1995. Lymnaea cousini Jousseaume, 1887 from Ecuador (Gastropoda: Lymnaeidae). Mem Inst Oswaldo Cruz 90: 605-609.

Paraense WL 2004. Planorbidae, Lymnaeidae, and Physidae of Ecuador (Mollusca: Basommatophora). Mem Inst Oswaldo Cruz 99: 357-362.

Patiño R 1978. Huéspedes Intermediarios de Fasciola hepatica en el Departamento de Antioquia, Thesis, Departamento de Biología, Universidad de Antioquia, Medellín, 33 pp.

Piaget J 1914. Voyage d'exploration scientifique en Colombie. Mém Soc Neuchâtel Sci Nat 5: 265-269.

Pilsbry HA 1935. South American land and freshwater mollusks. IX - Colombian species. Proc Acad Nat Sci Philadelphia 87: 83-88.

Pointier JP, Noya O, Amarista M, Therón A 2004. Lymnaea cousini Jousseaume, 1887 (Gastropoda: Lymnaeidae): First record for Venezuela. Mem Inst Oswaldo Cruz 99: 567569 .
Pointier JP, Yong M, Gutiérrez A 2005. Guide to the Freshwater Molluscs of Cuba, Conchbooks, Germany, $120 \mathrm{pp}$.

Samadi S, Roumegoux A, Bargues MD, Mas-Coma S, Yong M, Pointier JP 2000. Morphological studies of lymnaeid snails from the human fascioliasis endemic zone of Bolivia. $J \mathrm{Mol}$ Studies 66: 31-44.

Velásquez LE, Escobar JS 2001 Physa cubensis Pfeiffer, 1839 (Pulmonata: Physidae) en la sabana de Bogotá (Cundinamarca, Colombia). Act Biol 23: 75-80.

Villavicencio A, Carvalho de Vasconcellos M 2005 First report of Lymnaea cousini Jousseaume, 1887 naturally infected with Fasciola hepatica (Linnaeus, 1758) (Trematoda: Digenea) in Machachi, Ecuador. Mem Inst Oswaldo Cruz 100: 735-737.

WHO-World Health Organization 1995. Control of Foodborne Trematode Infections. WHO Technical Report Series No. 849. WHO, Geneva, 157 pp. 